\title{
ПЕДІАТРІЯ
}

УДК 612.1.017:616.127-008.6-053.6

DOI: $10.26565 / 2617-409 X-2019-3-08$

\section{ADAPTIVE POSSIBILITIES OF THE CARDIOVASCULAR SYSTEM IN ADOLESCENTS WITH NON-INFLAMMATORY DISEASES OF THE MYOCARDIUM, TAKING INTO ACCOUNT THE FUNCTIONING OF THE RIGHT VENTRICLE OF THE HEART}

\author{
Tetiana Holovko, Nataliya Shevchenko, Akpofure Egwonor, Boateng Henry Kwabena, \\ Chibale Denise Bwembya, Muselepete Patience, Okoronkwo Ugochukwu Paul
}

Mail for correspondence: golovko@karazin.ua

\begin{abstract}
Summary: Adaptation of the cardiovascular system to physical activity implies the development of functional or structural changes that should ensure the most efficient and economical use of energy during muscular contraction. The most studied data reactions in individuals engaged in various sports. The aim of our study was to study the functional changes of the heart, taking into account the functioning of the right and left ventricles of the heart and the adaptive capacity of the cardiovascular system in children with non-inflammatory diseases of the myocardium. Were examined 62 patients with non-inflammatory myocardial diseases, whose mean age was $14.56 \pm 0.24$ years. The control group consisted of 41 practically healthy peers. The functional state of the myocardium was assessed according to the results of the ultrasonic Doppler study of the heart in the " $M$ " and " $B$ " - modes, as well as in the mode of constant-wave and color scanning with a convex sensor using the standard method. To study tolerance to the minimum physical activity and its influence on the state of the cardiovascular system in children, a six-minute walk test was conducted. To assess the functional intensity of the cardiovascular system before and after the six-minute walk test, the following vegetative indices were calculated: an endurance coefficient according to the formula A. Quaasa and a double product. The vegetative Kerdo index and adaptation potential were calculated at rest. As a result of the study, it was found that in children with myocardial pathology, stress is observed in the adaptation mechanisms of the cardiovascular system, accompanied by a weakening of its functional capabilities and an increase in the work of the cardiac muscle at rest. This happens against the background of a decrease in the functioning of the left ventricle and an increase in the functioning of the right ventricle of the heart. These changes are accompanied by activation of the parasympathetic division of the autonomic nervous system in patients in all the studied groups, which indicates a more economical mode of functioning of the body systems.
\end{abstract}

Key words: cardiovascular system functioning, myocardial pathology, adolescents

\section{Information about author}

Tetiana Holovko, $\mathrm{PhD}$, associate professor, department of pediatric №2, V. N. Karazin Kharkiv National University, Svobody sq. 6, Kharkiv, Ukraine, 61022. https://orcid.org/00000003-3815-7874,golovko@karazin.ua

Nataliya Shevchenko, MD, head of pediatric department №2, V. N. Karazin Kharkiv National University, Svobody sq. 6, Kharkiv, Ukraine, 61022; MD leading research worker of Cardiology depertment State Institution "Institute for the Health of Children and Adolescents of the National Academy of Medical Sciences of Ukraine",
Yuvileinyi Avenue 52a, Kharkiv,

Ukraine, 61153.

mamagogi2002@gmail.com

https://orcid.org/0000-0003-4407-6050

Akpofure Egwonor, Student $6^{\text {th }}$

Course, V. N. Karazin Kharkiv National

University, Svobody sq. 6, Kharkiv,

Ukraine,

61022.

akpofure.eg@gmail.com

http://orcid.org/0000-0002-7468-3698

Boateng Henry Kwabena, Student, $6^{\text {th }}$ Course, V. N. Karazin Kharkiv National University, Svobody sq. 6, Kharkiv, Ukraine, 61022. amunike2g8@gmail.com

http://orcid.org/0000-0002-5512-2684
Chibale Denise Bwembya, Student, $6^{\text {th }}$ Course, V.N. Karazin Kharkiv National University, Svobody sq. 6, Kharkiv, Ukraine, 61022. bwembyachibale@gmail.com http://orcid.org/0000- 0001-6752-902X

Muselepete Patience, Student, $6^{\text {th }}$ Course, V.N. Karazin Kharkiv National University, Svobody sq. 6, Kharkiv, Ukraine, 61022. chandamuse@gmail.com http://orcid.org/0000-0002-3381-7979

Okoronkwo Ugochukwu Paul, Student, $6^{\text {th }}$ Course, V.N. Karazin Kharkiv National University, Svobody sq. 6, Kharkiv, Ukraine, 61022.

ugochukwupaulokoronkwo@gmail.com http://orcid.org/0000-0002-6673-4248 


\section{Introduction}

Adaptation of the cardiovascular system to physical activity implies the development of functional or structural changes that should ensure the most efficient and economical use of energy during muscle contraction. The most studied data are in individuals engaged in various sports $[2,6]$.

Changes in the activity of the cardiovascular

system, first of all the heart rate, are the most striking indicator of the deviations that occur in the regulatory systems and above all in the work of the autonomic nervous system. They precede hemodynamic, metabolic, energy disorders and may be the earliest prognostic signs of trouble in a patient $[6,10]$.Physical activity has a complex and

diverse effect on the body. It is known that conducting tests with physical exertion can provoke malignant and life-threatening cardiac arrhythmias, which in turn can lead to the development of sudden death syndrome [2,6].

With a large number of works devoted to the study of chronic heart failure (CHF) including in children, most of them relate to the study of the morphofunctional state of the left heart and the structure and function of the right are least taken into account. However, in scientific papers of the second half of the 20th century, a higher sensitivity of the right ventricle (RV) showed changes in both intra-cardiac hemodynamics as well as extracardiac influences to fluctuations in the pressure level of expulsion [3]. It was also described in the data that the pancreas has a higher adaptive capacity than the left ventricle, due to the more intensive functioning of some adaptive mechanisms and a biochemical study which established a much greater severity of lysosomes self-regulatory activity in the right ventricle [5].

The aim of our study was to study the functional changes of the heart, taking into account the functioning of the right and left ventricles of the heart and the adaptive capacity of the cardiovascular system in children with noninflammatory diseases of the myocardium.

\section{Materials and methods}

62 patients with non-inflammatory myocardial diseases were examined, 39 of them were boys and 23 girls, whose average age was $14.56 \pm 0.24$ years. This group included 30 patients with small abnormalities of heart development (SAHD) and
32 patients with various rhythm and conduction disorders (RCD). The group with SAHD included children with the presence of mitral valve prolapse of varying severity, mainly I degree without regurgitation or with regurgitation I degree, with tricuspid valve prolapse, abnormal chords in the left ventricle, expansion of the output path of the right ventricle [4]. Children with sinus nonparoxysmal tachycardia, right ventricular extrasystoles, supraventricular extrasystoles, and Wolff-Parkinson-White syndrome were included in the group with RCD. The control group consisted of 41 practically healthy adolescents, including 14 girls and 27 boys. The average age was $14.68 \pm 0.36$ years.

The functional state of the myocardium was assessed according to the results of the ultrasonic Doppler study of the heart (echocardiogram, Doppler- echocardiogram) in the " $M$ " and " $B$ " modes, as well as in the constant-wave and color scanning mode with a $5 \mathrm{MHz}$ convex sensor on the device digital ultrasound diagnostic system SA8000 Live (firm "Medison", Korea) according to the standard method recommended by the Ultrasound Diagnostic Association (UDA). Heart structures were recorded in five standard leads.

To assess the function of the myocardium, the following indicators were used: left ventricular ejection fraction (EFlv), right ventricular ejection fraction (EFrv), left ventricular stroke volume (SVlv), right ventricular stroke volume (SVrv), left ventricle minute volume (MVlv), right ventricle minute volume (MVrv). Since the calculation of the stroke volume includes an index of heart rate, for leveling the age-related parameters, the index of the stroke volume of the left ventricle (ISVlv) and the stroke volume of the right ventricle (ISVrv) were calculated [2].

In order to study tolerance to minimal physical activity and its influence on the state of the cardiovascular system (CVS) in children, a sixminute walk test (6MWT) was performed, which was carried out in the first half of the day in the conditions of the stationary corridor. The test took place at an individual maximum rapid pace (avoiding the appearance of pain, shortness of breath, muscle fatigue or heaviness in the legs, dizziness, weakness), ensuring that the patient passed the maximum distance for 6 minutes. The distance covered (6MWD) was measured in 
meters. The dynamics of the patient's clinical state were monitored at baseline and after the test. The heart rate (HR) and blood pressure (BP) were recorded before and after test. At the end of the test the percentage increase in heart rate was calculated (\% increase HR) $[2,11]$.

To assess the functional tension of the cardiovascular system the following vegetative indices were calculated before and after the 6MWT: endurance coefficient (EC) according to the formula of A. Quaasa and Robinson index (IR) or double product.

The endurance coefficient (EC) was calculated according to the formula A. Quaasa: $\mathrm{EC}=\mathrm{HR} /$ SBP - DBP, where HR - heart rate (number of beats per minute), SBP - systolic blood pressure $(\mathrm{mm} \mathrm{Hg})$, DBP - diastolic blood pressure (mm.rt.st.). An increase in this indicator indicates a weakening, and a decrease in this parameter indicates an increase in the functional capabilities of the CVS [10].

The Robinson index (IR) was determined by the formula: IR $=$ HR - SBP / 100, where HR is the heart rate (number of beats per minute), SBP is the systolic blood pressure $(\mathrm{mm} \mathrm{Hg})$. The larger this indicator, the more work the heart muscle produces [10].

To assess the effect of the autonomic nervous system (ANS) on the parameters of CVS, the vegetative Kerdo index (VIK) was determined based on a comparison of diastolic blood pressure (DBP) and heart rate (HR). It was calculated by formula: $\mathrm{VIK}=(1-\mathrm{DBP} / \mathrm{HR}) \times 100$.

With vegetative balance in the regulation of the cardiovascular system, the VIK tends to 0 . VIK values with a positive sign indicate an increase in catabolism processes characteristic of intense functioning with the expenditure of the body's energy reserves. VIK with a negative sign indicates a more favorable, anabolic variant of the shift and more economical mode of functioning of body systems $[7,8]$.

At rest, the functional changes index (FCI) of the circulatory system, or the adaptation potential (AP), was also determined. AP is calculated without load tests and allows you to give a preliminary quantitative assessment of the level of health of the subjects. AP of the circulatory system is determined by the formula:
$\mathrm{AP}=0,011 \times \mathrm{HR}+0,014 \times \mathrm{SBP}+0,008 \times \mathrm{DBP}+0,009 \times$

$\times \mathrm{BW}-0,009 \times \mathrm{H}+0,014 \times \mathrm{A}-0,27$,

where $\mathrm{HR}$ is the heart rate in relative rest (the number of beats per 1 minute); SBP - systolic blood pressure (mm Hg); DBP - diastolic blood pressure $(\mathrm{mm} \mathrm{Hg})$; $\mathrm{BW}$ is body weight $(\mathrm{kg}) ; \mathrm{H}$ height $(\mathrm{cm}) ; \mathrm{A}$ - age (years).

The results were evaluated as follows: less than or equal to 2.1 satisfactory adaptation, $2.11-3.2$ stress adaptation mechanisms, $3.21-4.3$ unsatisfactory adaptation, more than 4.31 failure of adaptation mechanisms (according to R.M. Baevsky, 1979) [9, 12].

Statistical processing of the obtained data was carried out using the SPSS17 application software package (license 4-180844250981ae3daes/nSPSS17) for IBM PC / Pentium-4. At the first stage, the arithmetic mean value and the standard error for it were calculated for all indicators. Discrepancies between averages in the case of a normal distribution of indicators were estimated by parametric (Student's t test, Fisher's angular transformation), and in the absence of a normal distribution by non-parametric (Wilcoxon-MannWhitney) methods of mathematical statistics.

\section{Results and Discussion}

When conducting an objective examination of patients, children from either the main group or the control group did not make any complaints about their state of health. During auscultation in children with SAHD, systolic murmur was found in the apex of the heart in $97 \%$ of patients (29 children). No changes were registered in children with RCD.

When assessing the functional parameters of the heart during EchoCG, all the parameters corresponded to the age norms. However, EFlv in children of the main group was significantly lower than in the control group. The lowest result of this indicator was observed in children with rhythm disorders. There was also a significant decrease in ISVlv in children with systemic dysplasia and in patients with rhythm disorders. These changes are accompanied by higher heart rate figures, especially in patients with arrhythmias (Table 1). 
Table 1. Functional indicators of the left and right ventricles of the heart in children with noninflammatory heart diseases in comparison with the control group. $(M \pm m)$

\begin{tabular}{|l|c|c|c|c|}
\hline \multicolumn{1}{|c|}{ Indicators } & $\begin{array}{c}\text { Main study group, } \\
\mathrm{n}=62\end{array}$ & $\begin{array}{c}\text { Subgroup with } \\
\text { SAHD, } \mathrm{n}=30\end{array}$ & $\begin{array}{c}\text { Subgroup with } \\
\text { RCD, n=32 }\end{array}$ & $\begin{array}{c}\text { Control group, } \\
\mathrm{n}=41\end{array}$ \\
\hline EFlv, \% & $63,90 \pm 0,96^{* *}$ & $64,59 \pm 1,29^{* *}$ & $63,25 \pm 1,42^{* *}$ & $69,69 \pm 0,78$ \\
\hline SVlv, $\mathrm{ml}$ & $58,62 \pm 2,54$ & $65,48 \pm 3,74^{* *}$ & $51,77 \pm 2,99^{* *}$ & $61,84 \pm 2,59$ \\
\hline ISVlv, $\mathrm{ml} / \mathrm{m}^{2}$ & $36,13 \pm 1,31$ & $38,49 \pm 1,80^{*}$ & $33,75 \pm 1,83^{*}$ & $38,91 \pm 1,30$ \\
\hline MVlv, l/min & $3,97 \pm 0,19$ & $4,31 \pm 0,29$ & $3,63 \pm 0,22^{*}$ & $3,90 \pm 0,21$ \\
\hline EFrv, \% & $60,05 \pm 1,39$ & $56,83 \pm 1,84$ & $63,06 \pm 1,95^{*}$ & $60,46 \pm 1,63$ \\
\hline SVrv, $\mathrm{ml}$ & $8,14 \pm 0,59$ & $7,51 \pm 0,57$ & $8,75 \pm 1,02$ & $7,44 \pm 0,40$ \\
\hline ISVrv, $\mathrm{ml} / \mathrm{m}^{2}$ & $5,01 \pm 0,33$ & $4,43 \pm 0,30$ & $5,58 \pm 0,57^{*}$ & $4,65 \pm 0,22$ \\
\hline MVrv, 1/min & $0,73 \pm 0,13^{*}$ & $0,67 \pm 0,19$ & $0,79 \pm 0,18^{*}$ & $0,48 \pm 0,03$ \\
\hline HR, b/min & $83,47 \pm 2,31^{* *}$ & $80,00 \pm 3,58^{*}$ & $86,72 \pm 2,89^{* *}$ & $73,57 \pm 1,72$ \\
\hline
\end{tabular}

Note: $* *$ - $\mathrm{p}<0.001 ; *$ - $\mathrm{p}<0.05$; when compared with similar indicators of the control group.

On the part of the right ventricle, opposite changes occurred. Thus, in children with rhythm disturbances, there is a significant increase in EFrv and ISVrv, which indicates an increase in the functioning of the right ventricle.

In the first half of the 20th century, P. Bernheim described in his works the concept of interventricular interaction, by which he understood the close relationship between the functioning of the right and left ventricles. It is based on the integrity of the structure of both ventricles, their blood supply and function. They also have the same anatomy of muscle fibers, a single interventricular septum, and pericardium. Also, the interaction of the ventricles is due to the influence of fluctuations in pressure and volume in the chest $[1,5]$.

Thus, in patients with non-inflammatory diseases of the heart while reducing the functioning of the left ventricle, the increased functioning of the right ventricle is noted, which is most pronounced in patients with arrhythmias.

When studying the functional ability of the myocardium in children with non-inflammatory heart diseases, the prevalence of the influence of the parasympathetic division of the ANS was revealed, as evidenced by the VIK values. In both the main and control groups, this index was with a negative sign, but it was significantly higher in patients of the main group, and its highest value was noted in patients with RCD, which indicates a higher activity of the sympathetic ANS in this category of children (Table 2) .

Adaptation potential in patients with noninflammatory myocardial diseases was significantly higher in the group as a whole. When analyzing this indicator in the selected subgroups, it was significantly higher in patients with SAHD, which indicates the stress of adaptation mechanisms in these children (Table 2).

Table 2. The functional ability of the cardiovascular system in children with non-inflammatory heart diseases in comparison with the control group alone. $(M \pm m)$

\begin{tabular}{|c|c|c|c|c|}
\hline Indicators & $\begin{array}{c}\text { Main study } \\
\text { group, } \mathrm{n}=62\end{array}$ & $\begin{array}{c}\text { Subgroup with } \\
\text { SAHD, } \mathrm{n}=30\end{array}$ & $\begin{array}{c}\text { Subgroup with } \\
\text { RCD, n=32 }\end{array}$ & $\begin{array}{c}\text { Control group, } \\
\mathrm{n}=41\end{array}$ \\
\hline Kerdo index & $-82,79 \pm 2,85$ & $-84,26 \pm 3,48$ & $-77,12 \pm 3,27$ & $-91,48 \pm 3,68$ \\
\hline Adaptation potential & $1,97 \pm 0,14 * *$ & $2,56 \pm 0,09 * *$ & $2,18 \pm 0,06 * *$ & $1,81 \pm 0,05$ \\
\hline
\end{tabular}

Note: $*^{*}-\mathrm{p}<0.001 ; *-\mathrm{p}<0.05$; when compared with similar indicators of the control group.

The distance covered during the six-minute walk test in patients with myocardial pathology was not significantly different from that of children in the control group. The endurance coefficient was significantly higher in children with myocardial pathology at rest due to children with arrhythmias. This indicates a weakening of the functional capabilities of the cardiovascular system in these patients at rest (Table 3). After $6 \mathrm{MWT}$, the endurance coefficient increased in all the analyzed groups, which also indicates a weakening of the CVS function in these childre 
Actual problems of modern medicine. Issue 3, 2019

Table 3. Exercise tolerance in children with non-inflammatory heart diseases in comparison with the control group before and after the six-minute walk test. $(M \pm m)$

\begin{tabular}{|c|c|c|c|c|c|c|c|c|}
\hline Indicators & $\begin{array}{l}\text { Main stu } \\
\mathrm{n}=62\end{array}$ & group, & $\begin{array}{l}\text { Subgroup } \\
\text { SAHD, n }\end{array}$ & $=30 \quad$ with & $\begin{array}{l}\text { Subgroup } \\
\mathrm{RCD}, \mathrm{n}=\end{array}$ & with & $\begin{array}{l}\text { Control } \\
n=41\end{array}$ & group, \\
\hline \multirow[t]{2}{*}{ 6MWD, m } & \multicolumn{2}{|c|}{$507,55 \pm 9,78$} & \multicolumn{2}{|c|}{$502,47 \pm 13,43$} & \multicolumn{2}{|c|}{$512,23 \pm 14,34$} & \multicolumn{2}{|c|}{$519,80 \pm 8,84$} \\
\hline & $\begin{array}{l}\text { Before } \\
6 \mathrm{MWT}\end{array}$ & $\begin{array}{l}\text { After } \\
6 \mathrm{MWT}\end{array}$ & $\begin{array}{l}\text { Before } \\
6 \mathrm{MWT}\end{array}$ & $\begin{array}{l}\text { After } \\
6 \mathrm{MWT}\end{array}$ & $\begin{array}{l}\text { Before } \\
6 \mathrm{MWT}\end{array}$ & $\begin{array}{l}\text { After } \\
\text { 6MWT }\end{array}$ & $\begin{array}{l}\text { Before } \\
6 \mathrm{MWT}\end{array}$ & $\begin{array}{l}\text { After } \\
\text { 6MWT }\end{array}$ \\
\hline $\begin{array}{l}\text { Endurance } \\
\text { coefficient }\end{array}$ & $\begin{array}{l}2,01 \\
0,08^{*}\end{array}$ & $\begin{array}{ll}2,31 \quad \pm \\
0,07\end{array}$ & $\begin{array}{ll}1,97 & \pm \\
0,15 & \end{array}$ & $\begin{array}{ll}2,27 & \pm \\
0,12 & \end{array}$ & $\begin{array}{l}2,05 \quad \pm \\
0,08 *\end{array}$ & $\begin{array}{ll}2,35 & \pm \\
0,08 & \end{array}$ & $\begin{array}{l}1,78 \quad \pm \\
0,11\end{array}$ & $\begin{array}{l}2,17 \pm \\
0,13\end{array}$ \\
\hline Robinson index & $\begin{array}{l}86,26 \pm \\
2,85\end{array}$ & $\begin{array}{l}121,56 \pm \\
4,32\end{array}$ & $\begin{array}{l}90,06 \pm \\
4,39 *\end{array}$ & $\begin{array}{l}123,18 \pm \\
6,29\end{array}$ & $\begin{array}{l}82,76 \\
\pm 3,63 *\end{array}$ & $\begin{array}{l}120,08 \pm \\
5,04\end{array}$ & $\begin{array}{l}81,39 \quad \pm \\
3,19\end{array}$ & $\begin{array}{l}114,28 \\
\pm 4,64\end{array}$ \\
\hline
\end{tabular}

Note: $* *$ - $p<0.001$; - p <0.05; when compared with similar indicators of the control group.

Also at rest, the values of the Robinson index in patients in the studied subgroups were significantly high, which suggests that the heart muscle in children with myocardial pathology does more work than in children of the control group. After 6MWT, this indicator increased in all studied children, but its increase did not have significant differences (Table 3).

\section{Conclusion}

Thus, in children with myocardial pathology, stress is observed in the adaptation mechanisms of the cardiovascular system, accompanied by a weakening of its functional capabilities and an increase in the work of the cardiac muscle in a state of rest. This happens against the background of a decrease in the functioning of the left ventricle and an increase in the functioning of the right ventricle of the heart. These changes are accompanied by activation of the parasympathetic division of the autonomic nervous system in patients in all the studied groups, which indicates a more economical mode of functioning of the body systems.

\section{References}

1. Buslenko N. (2005) The relationship between the functional state of the right ventricle and the degree of heart failure in patients with ischemic heart disease with a low contractile function of the left ventricle. Cardiology. 12, p. 25-30. [in Russian]

2. Holovko T.A. Adaptive possibilities of the cardiovascular system in children with myocardial pathology depending on the level of functioning of the right ventricle of the heart. International Journal of Pediatrics, Obstetrics and Gynecology. 3 (1), p. 27-32 3. [in Russian]

3. Zharinov O., Said S. \& Komorovskiy R. (2000) Right ventricular state and interventricular interaction in patients with chronic insufficiency. Kardiologiya. 11, p. 4549. [in Russian]
4. Zakharova Yu.V. (2011) Small anomalies of heart development in children as a manifestation of connective tissue dysplasia. Consilium Medicum Pediatriya. 2, p. 57-61 [in Russian]

5. Kazanskaya T. \& Frolov V. (1995) The right ventricle of the heart. Rosiyskiy universitet druzhby nardov. 1995, 199 p. [in Russian]

6. Pavlova, T., Pilkevich, N., \& Dychko, V. (2017). Izuchenie reaktsii serdechno-sosudistoy sistemy na fizicheskuyu nagruzku u shkolnikov v vozraste 11-14 let s patologiey zreniya [Study of the reaction of cardiovascular system on physical activity in schoolpupils aged 11-14 years with vision pathology]. Medical Herald of the South of Russia, 1, p. 70-74. [Russian].

7. Androshchuk O. I., \& Zavhorodnia, V. A. (2018). Correlation of vegetative tone indicator with Kerdo index and heart rate variability. Visnyk Cherkaskoho universytetu - Cherkasy University Bulletin, 4. Retrieved from https://doi: 10.31651/2076-5835-2018-1-1-3-6.

8. Martsenyuk V., Vakulenko D., \& Vakulenko L. (2013). Kerdo informative index to determine the level of autonomic regulation at osteochondrosis of the cervical Spine. Medical Informatics and Engineering. (1). Retrieved from https://doi.org/10.11603/mie.1996-1960.2013.1.418.

9. Martyniuk O. \&Vilyanskiy V. (2015) Assessment of students' health condition by indicators of adaptation potential, biological age and bio-energetic reserves of organism. Physical education of students. 3, p. 20-29. URL: http://nbuv.gov.ua/UJRN/PhVSTSE_2015_3_5

10. Molina G. E., Fontana K. E., Porto L. G. et al. (2016). Post-exercise heart-rate recovery correlates to resting heart-rate variability in healthy men. Official Journal of the Clinical Autonomic Research Society. 26(6), p. 415-421. Retrieved from http://doi: 10.1007/s10286-016-0378-2.

11. Chun-An C., Chin-Hao C., Ming-Tai L. et al. (2015). Six-Minute Walking Test: Normal Reference Values for Taiwanese Children and Adolescents. Acta Cardiologica Sinica The official journal of Taiwan Society of Cardiology. 31, p. 193-201. Retrieved from http: //doi: 10.6515/ACS20140721D.

12. Selivonenko S. (2001) The assessment of adaptation potential of circulatory system in noncoronarogenic myocardial disease. Klinicheskaia meditsina. 79(6), p. 26-28. Retrieved from PMID:11521374 [in Russian] 


\title{
АДАПТАЦЙНІ МОЖЛИВОСТІ СЕРЦЕВО-СУДИННОЇ СИСТЕМИ У ПІДЛІТКІВ 3

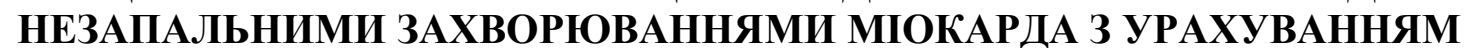 ФУНКЦІОНУВАННЯ ПРАВОГО ТА ЛІВОГО ШЛУНОЧКІВ
}

\author{
Головко Т.О., Шевченко Н.С., Акпофуре Е., Боатенг Г., Чібалє Д. Б., \\ муселепе П., Окоронкво У. П.
}

Пошта для листування: golovko@karazin.ua

Резюме: Адаптаиія сериево-судинної системи до фізичного навантаження передбачає розвиток функиіональних або структурних змін, які повинні забезпечити найбільш ефективне $i$ економне витрачання енергії при м'язовому скороченні. Найбільш вивчені дані реакиії у осіб, щяо займаються різними видали спорту. Метою нашого дослідження було вивчення функціональних змін серия 3 урахуванням функиіонування правого і лівого шлуночків серия $і$ адаптаційних можливостей сериевосудинної системи у дітей з незапальними захворюваннями міокарда. Обстежено 62 пацієнта 3 незапальними захворюваннями міокарда, середній вік яких був 14,56 0,24 років. Групу контролю склали 41 практично здорових ӥхніх однолітків. Функиіональний стан міокарда оцінювали за результатами ультразвукового доплерівського дослідження серия в " $M$ " - $i$ " $B$ " - режимах, а також в режимі постійнохвильового і кольорового сканування конвексним датчиком за стандартною методикою. Для вивчення толерантності до мінімальному фізичному навантаженні і ї̈ впливу на стан сериево-судинної системи y дітей проводився тест шестихвилинної ходьби. Для оиінки функиіональної напруженості сериевосудинної системи до і після тесту шестихвилинної ходьби розраховувалися наступні вегетативні індекси: коефіцієнт витривалості за формулою А. Квааса $i$ подвійне твір. У стані спокою розраховувалися вегетативний індекс Кердо і адаптаційний потенціал. В результаті дослідження отримано, щзо у дітей з патологією міокарда відзначається напруга механізмів адаптачії сериевосудинної системи, що супроводжується ослабленням функціональних ї̈ можливостей $i$ збільшенням роботи сериевого м'яза в стані спокою. Відбувається ие на тлі зниження функціонування лівого шлуночка $i$ збільшення функціонування правого шлуночка серия. Супроводжуються дані зміни активацією парасимпатичного відділу вегетативної нервової системи у пацієнтів у всіх досліджуваних групах, що вказує на більш економний режим функиіонування систем організму.

Ключові слова: функціонування серцево-судинної системи, патологія міокарда, підлітки

Інформація про авторів

Головко Тетяна Олексіївна, к. мед. н., доцент кафедри педіатрії №2, Харківський національний університет імені В.Н. Каразіна, 61022, Україна, м. Харків, пл. Свободи, 6. golovko@karazin.ua

https://orcid.org/0000-0003-3815-7874

Шевченко Наталія Станиславівна, д.мед.н., завідувач педіатричним відділенням №2, Харківський національний університет імені В.Н. Каразіна, 61022, Україна, м. Харків, пл. Свободи, 6; д.мед.н., провідний науковий співробітник кардіологічного відділення державної установи «Інститут здоров'я дітей і підлітків Національної академії медичних наук
України», , 61153, Україна, м. Харків, пр. Ювілейний, 52a mamagogi2002@gmail.com https://orcid.org/0000-0003-4407-6050 Акпофуре Егвонор, студент 6-го курсу, Харківський національний університет імені В.Н. Каразіна, 61022, Україна, м. Харків, пл. Свободи, 6. akpofure.eg@gmail.com

http://orcid.org/0000-0002-7468-3698

Боатенг Генрі Квабена, студент 6 курсу, Харківський національний університет імені В.Н. Каразіна, 61022 , Україна, м. Харків, пл. Свободи, 6. amunike2g8@gmail.com

http://orcid.org/0000-0002-5512-2684
Чібале Деніз Бвембья, студентка6-го курсу Харківського національного університету імені В.Н. Каразіна, 61022, Україна, м. Харків, пл. Свободи, 6. bwembyachibale@gmail.com

http://orcid.org/0000-0001-6752-902X

Муселепете Терпіння, студентка 6 курсу, Харківський національний університет імені В.Н. Каразіна, 61022, Україна, м. Харків, пл. Свободи, 6. chandamuse@gmail.com http://orcid.org/0000-0002-3381-7979

Окоронкво В. П, студент 6-го курсу, Харківський національний університет імені В.Н. Каразіна, 61022, Україна, м. Харків, пл. Свободи, 6. ugochukwupaulokoronkwo@gmail.com http://orcid.org/0000-0002-6673-4248 


\title{
АДАПТАЦИОННЫЕ ВОЗМОЖНОСТИ СЕРДЕЧНО-СОСУДИСТОЙ СИСТЕМЫ У ПОДРОСТКОВ С НЕВОСПАЛИТЕЛЬНЫМИ ЗАБОЛЕВАНИЯМИ МИОКАРДА С УЧЕТОМ ФУНКЦИОНИРОВАНИЯ ПРАВОГО И ЛЕВОГО ЖЕЛУДОЧКОВ
}

\author{
Головко Т.А, Шевченко Н.С, Акпофуре Е., Боатенг Г., Чибале Д.Б., \\ муселепе П., Окоронкво В. П.
}

Почта для переписки: golovko@karazin.ua

\begin{abstract}
Резюме: Адаптация сердечно-сосудистой системы к физической нагрузке предполагает развитие функииональных или структурных изменений, которые должны обеспечить наиболее эффективное и экономное расходование энергии при мымечном сокращении. Наиболее изучены данные реакиии у лии, занимающихся различными видами спорта. Целью намего исследования было изучение функииональных изменений сердиа с учетом функиионирования правого и левого желудочков сердиа и адаптационных возможностей сердечно-сосудистой системы у детей с невоспалительными заболеваниями миокарда. Обследовано 62 пачиента с невоспалительными заболеваниями миокарда, средний возраст которых был 14,56士0,24 лет. Группу контроля составили 41 практически здоровых их сверстников. Функциональное состояние миокарда оценивалось по результатам ультразвукового доплеровского исследования сердиа в " $M$ "- и "B"- режимах, а также в режиме постоянно-волнового и цветного сканирования конвексным датчиком по стандартной методике. Для изучения толерантности к минимальной физической нагрузке и ее влияния на состояние сердечно-сосудистой системы у детей проводился тест шестиминутной ходьбы. Для оиенки функииональной напряженности сердечно-сосудистой системы до и после теста шестиминутной ходьбы рассчитыввались следующие вегетативные индексы: коэффициент выносливости по формуле А. Квааса и двойное произведение. В состоянии покоя рассчитывались вегетативный индекс Кердо и адаптационный потенциал. В результате исследования получено, что у детей с патологией миокарда отмечается напряжение механизмов адаптаиии сердечно-сосудистой системы, сопровождающееся ослаблением функииональных ее возможностей и увеличением работь сердечной мышиы в состоянии покоя. Происходит это на фоне снижения функционирования левого желудочка и увеличения функиионирования правого желудочка сердиа. Сопровождаются данные изменения активацией парасимпатического отдела вегетативной нервной системы у пациентов во всех исследуемых группах, что указывает на более экономный режим функиионирования систем организма.
\end{abstract}

Ключевые слова: функционирование сердечно-сосудистой системы, патология миокарда, подростки

Информация об авторах

Головко Татьяна Алексеевна, к. мед. н., доцент кафедры педиатрии №2, Харьковский национальный университет имени В.Н. Каразина, пл. Свободы, 6, г. Харьков Украина, 61022. golovko@karazin.ua https://orcid.org/0000-0003-3815-7874

Шевченко Наталия Станиславовна, д.мед.н., заведующая педиатрическим отделением №2, Харьковский национальный университет имени В.Н. Каразина, пл. Свободы, 6, г. Харьков Украина, 61022; д.мед.н., ведущий научный сотрудник кардиологического отделения ГУ «Институт охраны здоровья детей и подростков Национальной академии медицинских наук Украины», проспект
Ювилейный, 52а, г. Харьков, Украина, 61153. mamagogi2002@gmail.com https://orcid.org/0000-0003-4407-6050 Акпофуре Эгвонор, студент 6-го курса, Харьковский национальный университет имени В.Н. Каразина, пл. Свободы, 6, г. Харьков Украина, 61022. akpofure.eg@gmail.com

http://orcid.org/0000-0002-7468-3698 Боатенг Генри Квабена, студент 6 курса, Харьковский национальный университет им. В. Н. Каразина, пл. Свободы, 6, г. Харьков Украина, 61022. amunike2g8@gmail.com

http://orcid.org/0000-0002-5512-2684

Чибале Дениз Бвембья, студентка 6го курса Харьковский национальный университет имени В.Н. Каразина, пл. Свободы, 6, г. Харьков Украина, 61022. bwembyachibale@gmail.com http://orcid.org/0000-0001-6752-902X

Муселепете Терпение, студентка 6 курса, Харьковский национальный университет имени В.Н. Каразина, пл. Свободы, 6, г. Харьков Украина, 61022, chandamuse@gmail.com http://orcid.org/0000-0002-3381-7979

Окоронкво В. П, студент 6-го курса, Харьковский национальный университет имени В.Н. Каразина, пл. Свободы, 6, г. Харьков Украина, 61022 ugochukwupaulokoronkwo@gmail.com http://orcid.org/0000-0002-6673-4248

Conflicts of interest: author has no conflict of interest to declare.

Конфлікт інтересів: відсутній.

Конфликт интересов: отсутствует 